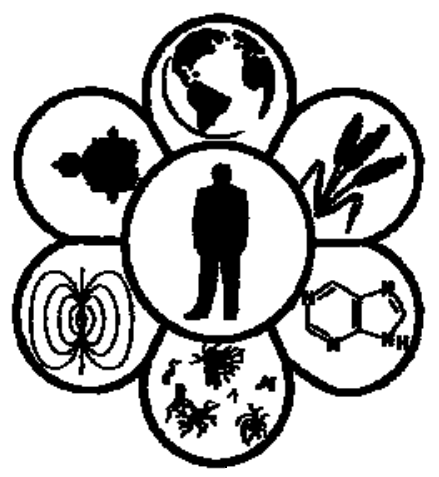

Вісник Дніпропетровського університету. Біологія, медицина Vìsnik Dnìpropetrovs'kogo unìversitetu. Serîa Bìologîâ, medicina Visnyk of Dnipropetrovsk University. Biology, medicine

Vìsn. Dnìpropetr. Unìv. Ser. Bìol. Med. 2015. 6(2), 125-132. doi: $10.15421 / 021523$

ISSN 2310-4155 print ISSN 2312-7295 online

www.medicine.dp.ua

UDC [57.04+616.5]616-003+616-008

\title{
Biochemical mechanisms of skin radiation burns inhibition and healing by the volumetric autotransplantation of fibroblasts and of keratinocytes with fibroblasts composition
}

\author{
L.V. Altukhova, K.V. Kot, Y.G. Kot, K.S. Morozova, Y.E. Persky \\ V.N. Karazin Kharkiv National University, Kharkiv, Ukraine
}

\begin{abstract}
Mechanisms of influence of volumetric autotransplantation of fibroblasts and of the mixture of fibroblasts and keratinocytes on the development of the local 3rd degree X-ray burn and the radiation skin ulcer in guinea pigs were investigated. We used deep administration into the irradiation zone on its perimeter of 6 doses, which contained $(150-160) \times 10^{3}$ fibroblasts and $(130-140) \times 10^{3}$ keratinocytes in $100 \mu$ l. It is shown that this autotransplantation carried out 1 hour after the irradiation, and then every 24 hours, reduces the area of burn on the 35th day, compared to the control by $63 \%$. Radiation ulcer appears on the 10th day after irradiation and is completely healed on the 25 th day. With the same regimen of administration of only fibroblasts containing $(200-210) \times 10^{3}$ cells in $100 \mu 1$, these parameters of treatment were equal to $31 \%$ on 4 th and 35th day, respectively. It is shown that as a result of radiation in the area of burn the level of gene expression of collagen types I and III, elastin, fibronectin, vinculin, decorin, hyaluronan synthases 1, 2, 3, matrix metalloproteinases 1, 2, 3, 7, 9 and hyaluronidase is reduced. Besides, in the burn area the level of gene expression of transforming growth factor $\alpha$, fibroblast growth factors 1 , 2,8 and anti-inflammatory cytokines - interleukin 10 and transforming growth factor- $\beta 1$ - is reduced, while the level of gene expression of proinflammatory cytokine (interleykin $1 \beta$ ) increases. Both types of autotransplantation cause the growth of the expression level of all the structural genes and regulatory proteins of biopolymers and decrease in the expression level of interleukin $1 \beta$, which leads to activation of tissue regeneration and healing of the burn wound. Reasons for the higher efficiency of autotransplantation using the mixture of fibroblasts and keratinocytes compared to autotransplantation by fibroblasts only are both the larger total number of live cells regularly replacing dead cells in the burn area, and mutual stimulation of auto-fibroblasts and auto-keratinocytes to proliferate and to synthesize biologically active substances, i.e. cytokines and growth factors.
\end{abstract}

Keywords: radiation burn; radiation ulcer; fibroblasts; keratinocytes; volumetric transplantation

\section{Биохимические механизмы ингибирования}

\section{и заживления лучевого ожога кожи объемной аутотрансплантацией фибробластов и композиции фибробластов с кератиноцитами}

\author{
Л.В. Алтухова, К.В. Кот, Ю.Г. Кот, К.С. Морозова, Е.Э. Перский
}

\section{Харьковский национальный университет имени В.Н. Каразина, Харьков, Украина}

Проведено исследование механизмов влияния объемной аутотрансплантаци фибробластами и смесью фибробластов с кератиноцитами на развитие локального рентгеновского ожога III степени и лучевой язвы кожи у морских свинок. Использовано глубокое введение в зону облучения по ее периметру 6 доз, содержащих $(150-160) \times 10^{3}$ фибробластов и $(130-140) \times 10^{3}$ кератиноцитов в 100 мкл. Показано, что эта аутотрансплантация, производимая через 1 час, а затем каждые 24 часа после облучения, к 35-м суткам уменьшает площадь ожога по сравнению с контролем на 63\%. Лучевая язва возникает на 10 -е сутки после облучения и полностью заживает к 25-м суткам. При такой же схеме введения одних фибробластов с содержанием $(200-210) \times 10^{3}$ в 100 мкл эти показатели лечения составляют $31 \%, 4$ и 35 суток соответственно. В результате облучения в зоне ожога снижается уровень экспрессии генов коллагена типов I и III, эластина, фибронектина, винкулина, декорина, гиалуронансинтаз 1, 2 и 3, матриксных металлопротеиназ 1 , $2,3,7$ и 9 и гиалуронидазы. В зоне ожога снижен также уровень экспрессии генов трансформирующего фактора роста $\alpha$, факторов роста фибробластов 1,2 и 8 и противовоспалительных цитокинов - интерлейкина 10 и трансформирующего фактора роста $\beta 1$, а 
уровень экспрессии гена провоспалительного цитокина - интерлейкина1 $\beta$ - повышен. Оба вида аутотрансплантации вызывают повышение уровня экспрессии всех генов структурных биополимеров, генов фибронектина, винкулина, декорина, гиалуронансинтаз 1, 2 и 3, а также матриксных металлопротеиназ 1, 2, 3, 7 и 9 и гиалуронидазы. Уровень экспрессии гена интерлейкина1 $\beta$ снижается, что приводит к активации процессов регенерации тканей и заживления ожоговой раны. Абсолютные изменения уровней экспрессии всех этих генов больше при введении в зону ожога смеси аутофибробластов с аутокератиноцитами. Причинами более высокой эффективности аутотрансплантации смесью фибробластов с кератиноцитами по сравнению с аутотрансплантацией одними только фибробластами являются как большее суммарное количество живых клеток, регулярно замещающих в зоне ожога погибшие клетки, так и взаимная стимуляция аутофибробластов и аутокератиноцитов к пролиферации и синтезу биологически активных веществ - цитокинов и факторов роста.

\section{Ключевые слова: лучевой ожог; лучевая язва; фибробласты; кератиноциты; аутотрансплантация}

\section{Introduction}

Currently, one the most perspective directions of the treatment of skin radiation burns and, especially, of radiation ulcers, is the cell therapy, in which autologous mesenchymal stromal cells, dermal fibroblasts and keratinocytes are used most commonly. Application of these cells to the affected area significantly reduces the degree of inflammation and stimulates the regeneration process in the ulcer area (Gerasimova and Nazarenko, 2005; Tenenhaus and Rennekampff, 2007; Bushmanov, 2012; Ryan, 2012; Eldashov, 2013). However, there is information that the use of stem cells in therapy is associated with the risk of their transformation into cancer cells (Herberts et al., 2011; Hatzistergos et al., 2011; Haubner et al., 2012; Miao, 2014). At the same time, absolute safety of autogenous dermal fibroblasts and keratinocytes is proved. Standard techniques of using of these cells lay in their usually separate application in the form of suspensions or cell layers on burn wounds with already formed necrotic ulcers (Rennekampff, 1997; Paramonov et al., 2000; Shapovalov et al., 2005; Benderitter, 2010). In works (Altuhova et al., 2013; Kot et al., 2013) it is shown that more effective therapy is not an application on wound surface of autologous fibroblasts, but their administration into the volume of the irradiated area, which captures all the layers of skin and subcutaneous tissues. Regular administration of the cells, which begins immediately after irradiation, inhibits the development of the burn and formation of the radiation ulcer.

There is a system of positive feedbacks between interacting fibroblasts and keratinocytes in vivo, which is based on production and secretion of substances that stimulate mutual proliferation of these cells and tissue regeneration (Marionnet and Pierrard, 2006; Varani and Perone, 2007; Werner et al., 2007; Yim et al., 2010; Huang and Burd, 2012; Rowan et al., 2015). Therefore, the administration of the mixture of auto-fibroblasts and auto-keratinocytes into the irradiated area should result in more effective healing of the burn than the administration of fibroblasts only.

In the present study the intensity of the biological mechanisms underlying the inhibition of development and the burn healing when fibroblasts only and the suspension composed of a mixture of fibroblasts and keratinocytes used for autotransplantation was compared.

\section{Materials and methods}

Experiments have been carried out on guinea pigs weighing $350-450 \mathrm{~g}$. When carrying out the experiments we followed recommendations of the standard of biomedical ethics of the European convention "For the protection of vertebrate animals used for experimental and other scientific purposes" (ETS No. 170, 1998) and the Law of Ukraine "On protection of animals against ill treatment, 2006" (Law of Ukraine No. 3447-IV, 2006).

Radiation burns of 3rd degree of the skin of the animals' left thigh were caused by $\mathrm{X}$-ray $\mathrm{CuK} \alpha$-radiation at dose rate of $4.25 \mathrm{~Gy} / \mathrm{min}$ for 14.1 minutes while irradiating the shaved skin area of $1.5 \mathrm{~cm}^{2}$ on the left hind paw thigh (Rennekampff et al., 1997). On 32nd day before the irradiation the skin biopsies from a right thigh of animals under ether anesthesia were taken. Skin wounds after a biopsy were completely healed on the 15th day. Primary cultures of fibroblasts and keratinocytes which were sub-cultured by standard methods for these cells (Rittié, 2005) and (Shaw, 1996; Takagi at al., 2011; Groeber et al., 2012) respectively were obtained from biopsies. Both cell types of the third passage stored in liquid nitrogen were used in the experiment (Keller, 2000).

The animals were divided into 4 groups. The first one included non-irradiated animals. The irradiated animals of the second group were not treated. In 1 hour after the irradiation, and then every 24 hours the third group of animals, which were being treated, was administered by suspension containing $(200-210) \times 10^{3}$ fibroblasts in $100 \mu \mathrm{l}$, and the fourth group - by a mixture of suspensions containing (150$160) \times 10^{3}$ fibroblasts and $(130-140) \times 10^{3}$ keratinocytes in $100 \mu \mathrm{l}$ of sterile saline for injection. 6 subcutaneous injections were made on the perimeter of the irradiation zone at an angle $45^{\circ}$ to its center at a depth of $1 \mathrm{~mm}$. The content of living cells in the suspension was $80-85 \%$. On the first day, and then at intervals of 72 hours during 35 days prior to each administration of autologous cells, in irradiated animals of all the three groups the overall area of the burn and a burn ulcer were measured by photomicrography and using the program ImageJ 2x 2.1.4.7 ud2 and Imaris 7.2.3 (Imaris, 2011). On the 20th and 35th day the irradiated animals of all the groups were decapitated under sodium thiopental effect, and histological preparations of skin were prepared with the area of burn (Penn Medicine, 2012). The same preparations were prepared with analogous sites of skin of non-irradiated animals. The number of living cells per $1 \mathrm{~mm}^{2}$ of burn wound (Histomix, 2012) and the area (\%) occupied in it by total collagen (Histomix, 2010), collagen type I (FITC-conjugated monoclonal antibody Invitrogen) (Histomix, 2008) and glycosaminoglycans (Histopathology, 2013) were microscopically measured in preparations.

The same measurements were carried out in preparations of non-irradiated animals' skin.

In the histological preparations of skin with a burn area of irradiated and analogous areas of skin of intact animals the gene expression of extracellular matrix proteins, enzymes participating in the metabolism of collagen and glycosaminoglycans, pro-inflammatory and anti-inflammatory inter- 
leukins, transforming growth factors and fibroblast growth factors were measured. For this purpose the skin, enclosed in paraffin blocks, was deparaffinized after formalin fixation, and RNA was isolated from it with using of kits "Qiagen RNeasy FFPE Kit" according to the original instruction of the manufacturer (Qiagen, 2013).

RNA concentration in the extracts was determined using the scanning UV-spectroscopy. The absorbance was measured at $260 \mathrm{~nm}$ in quartz micro-cuvettes Fisher Scientific of $400 \mu$ l volume with optical path length of $10 \mathrm{~mm}$. RNA concentration in the eluates was equal to $27 \mu \mathrm{g} / \mathrm{ml}$. The ratio of the absorbance at 260 and $280 \mathrm{~nm}$ was $1.8-1.9$, indicating high purity of RNA in the solutions investigated. Reverse transcription was conducted by synthesizing cDNA using the QIAGEN OneStep RT-PCR Kit according to the original instruction of the manufacturer (Qiagen, 2015). In our work we used gene-specific primers and Cy3-labeled nucleotides manufactured by Arrayit Life Technologies (USA), respectively. Amplification was carried out using the thermocycler BIO-RAD iCycler. Hybridization was performed on the DNA microarray manufactured by Arrayit (USA) according to the original instruction of the manufacturer (Arrayit, 2015). The individual chambers for hybridization SecureSeal were used for washing (Invitrogen, 2015). The chips were scanned on the confocal fluorescence scanner Affymetrix
428 using the Jaguar software. Scanning mode was as follows: slide size $25 \times 75 \times 1 \mathrm{~mm}$, resolution 10 microns, wavelengths of excitation and emission of fluorescence 532 and $570 \mathrm{~nm}$, respectively. The obtained fluorescence values were expressed in fluorescence units $/ \mathrm{mg}$ of tissue.

Determination of the content of pro-inflammatory and anti-inflammatory interleukins in blood serum was carried out by immunoenzyme method using reagents of ELISA kits manufactured by DRG Diagnostics (Germany), according to the original instruction of the manufacturer (Laboratornaja Diagnostika, 2015).

Analysis and statistical processing of the results of experiments were carried out with the software package Origin 7.5 pro using Normality Test and Two-Sample T-Test modules $(n=6)$. Results were expressed as $M \pm s d$, where $M-$ arithmetic mean, $\mathrm{SD}-$ standard deviation. Results with $\mathrm{P}<$ 0.05 were considered as reliable.

\section{Results and Discussion}

Table 1 shows the numerical values of the changes of areas of radiation burns and radiation skin ulcers in treated animals in relation to these areas in untreated irradiated animals in two variants of autotransplantation.

Effect of autotransplantation of fibroblasts and the mixture of fibroblasts and keratinocytes

Table 1 on the dynamics of the relative change of areas of radiation skin burns and radiation ulcers in guinea pigs (\%)

\begin{tabular}{|c|l|c|c|c|c|c|c|c|c|}
\hline \multirow{2}{*}{$\begin{array}{c}\text { Studied } \\
\text { area }\end{array}$} & \multirow{2}{*}{ Terms of animals treatment } & \multicolumn{5}{|c|}{ Twenty-four hours after the irradiation } \\
\cline { 3 - 8 } & & 1 & 4 & 7 & 10 & 15 & 20 & 25 \\
\hline \multirow{3}{*}{ Burn } & fibroblasts & $33.3 \pm 2.4^{\#}$ & $50.0 \pm 3.5^{+\#}$ & $56.8 \pm 3.1^{\#}$ & $63.2 \pm 3.5^{+\#}$ & $92.0 \pm 4.1^{+\#}$ & $80.3 \pm 3.7^{+\#}$ & $69.0 \pm 2.7^{+\#}$ & $44.3 \pm 1.9^{+\#}$ \\
\cline { 2 - 8 } & fibroblasts and keratinocytes & $33.3 \pm 2.0^{\#}$ & $39.6 \pm 2.5^{+\#}$ & $50.6 \pm 2.3^{+\#}$ & $58.8 \pm 1.6^{+\#}$ & $71.5 \pm 3.4^{+\#}$ & $78.2 \pm 3.3^{\#}$ & $37.0 \pm 2.1^{+\#}$ & $14.4 \pm 2.3^{+\#}$ \\
\hline \multirow{2}{*}{ Ulcer } & fibroblasts & 0 & $4.1 \pm 0.5^{+\#}$ & $52.0 \pm 2.0^{+\#}$ & $22.6 \pm 1.7^{+\#}$ & $58.8 \pm 2.8^{+\#}$ & $10.5 \pm 1.4^{+\#}$ & $9.8 \pm 1.1^{\#}$ & 0 \\
\cline { 2 - 8 } & fibroblasts and keratinocytes & 0 & 0 & 0 & $11.3 \pm 1.3^{+\#}$ & $14.4 \pm 1.5^{\#}$ & $3.8 \pm 0.6^{+\#}$ & $0^{+}$ & 0 \\
\hline
\end{tabular}

Note: ${ }^{\#}$ - reliable $(\mathrm{P}<0.05)$ relatively to irradiated untreated animals; ${ }^{+}-$reliable $(\mathrm{P}<0.05)$ relatively to animals which were treated with fibroblasts on the previous day.

As is evident, both types of autotransplantation compared with untreated animals inhibit the development of burn and accelerate the healing of radiation ulcer, but with different efficiency. Thus, on the 35 th day the relative area of burn when administered by the mixture of fibroblasts with keratinocytes is three times less than when administered by fibroblasts only. When fibroblasts only are administered, the radiation ulcer appears on the 4th day, reaches maximum size on the 15 th and is completely healed on the 35 th day, while in case of administration of the mixture of fibroblasts and keratinocytes it occurs on 10th, 15 th and 25 th day, respectively.

Table 2 shows the histological parameters of collagen and glycosaminoglycans content in supramolecular formations of the extracellular matrix of skin when administering only fibroblasts and the mixture of fibroblasts and keratinocytes in the irradiation zone during the process of formation, development and growth of the burn. As is seen, both the content of total collagen and collagen type I, which is a part of the most generated, "matured" supramolecular formations of matrix, as well as total glycosaminoglycans, decreases dramatically in the extracellular matrix of the irradiated nontreated animals as compared to non-irradiated animals throughout the observation period. Administration of autofibroblasts on the 20th and 35th day after irradiation in- creases the total content of collagen in the burn zone of irradiated treated animals up to $74 \%$ and $83 \%$, compared to nonirradiated ones. Administration of the mixture of autofibroblasts and auto-keratinocytes completely normalizes the content of collagen in the area of burn already on the 20th day after irradiation, and on 35th day it even slightly exceeds it, amounting $110 \%$ of the control. Similarly, both types of autotransplantation normalize glycosaminoglycans content in the burn zone, but to different degrees.

In the animals treated with auto-fibroblasts the content of glycosaminoglycans in the burn on the 20th and 35th day after irradiation is higher than that of non-irradiated ones, and is equal to $130 \%$ and $170 \%$, respectively. At the same time, autotransplantation with the mixture of fibroblasts and keratinocytes already on the 20th day after irradiation completely normalizes the content of glycosaminoglycans in the burn, and on 35th day, it is only slightly below normal. The dramatic decrease in the content of structural biopolymers of the extracellular matrix is the result of mass death of connective tissue cells in the area of X-ray burn (Paramonov, 2000; Kligunenko, 2005; Gerasimova, 2005; Tenenhaus and Rennekampff, 2007). Their destruction leads to the dramatic shift of the exchange of structural biopolymers of connective tissue matrix in the direction of degradation. This occurs due to the decrease of 
biopolymer synthesis because of reduction of the living cells number, and as a result of activation of the enzymatic cleavage, in particular, by acidic cathepsins which come out to the extracellular environment during cell destruction.
Thus, in irradiated non-treated animals the number of living cells in the wound amounts to only $17 \%$ and $10 \%$ on the 20 th and 35th days, respectively, on their number on the same area of non-irradiated animals' skin.

Table 2

Effect of autotransplantation of fibroblasts and the mixture of fibroblasts and keratinocytes on the number of living cells, collagen and glycosaminoglycans (GAG) content in the area of radiation skin burn of guinea pigs

\begin{tabular}{|c|c|c|c|c|c|c|}
\hline \multirow{3}{*}{$\begin{array}{l}\text { Days after } \\
\text { irradiation }\end{array}$} & \multirow{2}{*}{\multicolumn{2}{|c|}{$\begin{array}{l}\text { The irradiation and treatment } \\
\text { of animals conditions }\end{array}$}} & \multirow{2}{*}{$\begin{array}{c}\text { The number of } \\
\text { living cells in the } \\
\text { total area, } 10^{4} / \mathrm{mm}^{2}\end{array}$} & \multicolumn{3}{|c|}{$\begin{array}{l}\text { The area occupied by the biopolymers } \\
\text { in the general burn area, } \%\end{array}$} \\
\hline & & & & total collagen & collagen type I & GAG \\
\hline & non-irradiated & & $2.5 \pm 0.1$ & $33.1 \pm 1.8$ & $32.6 \pm 1.4$ & $20.4 \pm 1.1$ \\
\hline \multirow{3}{*}{20} & \multicolumn{2}{|l|}{ irradiated non-treated } & $0.5 \pm 0.1^{\#}$ & $25.0 \pm 1.5^{\#}$ & $23.1 \pm 0.9^{\#}$ & $11.6 \pm 0.8^{\#}$ \\
\hline & \multirow{2}{*}{ autotransplantation } & fibroblasts & $1.7 \pm 0.2^{\#}$ & $27.8 \pm 1.2^{\#}$ & $31.5 \pm 1.1$ & $25.8 \pm 1.5^{\#}$ \\
\hline & & fibroblasts and keratinocytes & $2.3 \pm 0.1^{+}$ & $32.4 \pm 1.3^{+}$ & $32.1 \pm 1.3$ & $21.1 \pm 1.2^{+}$ \\
\hline \multirow{3}{*}{35} & \multicolumn{2}{|c|}{ irradiated non-treated } & $0.3 \pm 0.1^{\#}$ & $18.3 \pm 1.5^{\#}$ & $16.4 \pm 1.5^{\#}$ & $5.1 \pm 0.6^{\#}$ \\
\hline & \multirow{2}{*}{ autotransplantation } & fibroblasts & $2.4 \pm 0.1$ & $29.2 \pm 1.3^{\#}$ & $27.0 \pm 1.2^{\#}$ & $32.9 \pm 2.1^{\#}$ \\
\hline & & fibroblasts and keratinocytes & $3.2 \pm 0.1^{+}$ & $37.8 \pm 2.1^{+}$ & $36.9 \pm 2.3^{+}$ & $17.7 \pm 1.4^{\#+}$ \\
\hline
\end{tabular}

Note: ${ }^{\#}$ - reliable $(\mathrm{P}<0.05)$ relatively to non-irradiated animals; ${ }^{+}-$reliable $(\mathrm{P}<0.05)$ relatively to animals which were treated with fibroblasts on the corresponding day.

When fibroblasts are administered after the irradiation of animals, their number in the burn amounts to $67 \%$ and $95 \%$ at these terms compared to the control. Administration of the mixture of keratinocytes and fibroblasts into the burn zone normalizes the number of living cells in it on the 20th day, and on the 35 th day it already exceeds $26 \%$ (Table 2 ). Naturally, these effects are primarily the consequence of increasing content of living cells in the area of radiation damage as a result of autotransplantation. Constant replacement of dying cells by living ones shifts the cellular metabolism in the affected zone toward the normalization. It is based on the increase in expression of the constructional and regulatory proteins genes, genes of the enzymes synthesizing glycosaminoglycans, as well as proteases and hyaluronidases genes, specific for each of these types of biopolymers. In the af- fected area in irradiated non-treated animals the expression of genes of collagen type I and III and elastin, which constitute the whole basis of collagen and elastin fibers in the skin derma, decreases continuously throughout the experiment and on the 35th day after irradiation almost vanishes.

In the similar manner, expression of genes of fibronectin, decorin and vinculin changes (Table 3). The first glycoprotein binds collagen fibrils which are being formed, and regulates the attaching of connective tissue cells to them (Miyamoto, 1998), the second one is the cytoskeleton protein, which together with the integral cell membrane protein participates in the formation of cell contacts with extracellular matrix, and the third protein regulates the correct assembly of collagen fibers formed (Reed, 2002).

Effect of autotransplantation of fibroblasts and the mixture of fibroblasts and keratinocytes on the expression of genes of constructional and minor proteins which form the extracellular matrix in the area of radiation skin burn of guinea pigs (rflu/mg of tissue $) \times 10^{4}$

\begin{tabular}{|c|c|c|c|c|c|c|c|c|}
\hline \multirow{4}{*}{\begin{tabular}{|c} 
Days \\
after \\
irra- \\
diation
\end{tabular}} & \multirow{3}{*}{\multicolumn{2}{|c|}{$\begin{array}{c}\text { The irradiation and treatment } \\
\text { of animals conditions }\end{array}$}} & \multicolumn{6}{|c|}{ Protein and its gene } \\
\hline & & & $\begin{array}{c}\alpha 1 \text {-chain of } \\
\text { collagen type I }\end{array}$ & $\begin{array}{c}\alpha 1 \text {-chain of } \\
\text { collagen type III }\end{array}$ & elastin & fibronectin & vinculin & decorin \\
\hline & & & Col1 $\alpha 1$ & Col3a1 & ELN & FN1 & VCL & DCN \\
\hline & \multirow{2}{*}{\multicolumn{2}{|c|}{$\begin{array}{l}\text { non-irradiated } \\
\text { irradiated non-treated }\end{array}$}} & $432.4 \pm 38.9$ & $251.1 \pm 62.7$ & $246.2 \pm 78.8$ & $169.6 \pm 1.6$ & $121.6 \pm 2.4$ & $90.1 \pm 8.4$ \\
\hline \multirow{3}{*}{20} & & & $2.3 \pm 0.20^{\#}$ & $1.3 \pm 0.30^{\#}$ & $1.3 \pm 0.40^{\#}$ & $0.9 \pm 0.01^{\#}$ & $0.3 \pm 0.01^{\#}$ & $0.4 \pm 0.04^{\#}$ \\
\hline & \multirow[b]{2}{*}{ autotransplantation } & fibroblasts & $20.6 \pm 1.8^{\#}$ & $19.2 \pm 4.8^{\#}$ & $1.1 \pm 0.30^{\#}$ & $0.7 \pm 0.01^{\#}$ & $0.2 \pm 0.01^{\#}$ & $0.3 \pm 0.03^{\#}$ \\
\hline & & \begin{tabular}{|l|} 
fibroblasts and \\
keratinocytes
\end{tabular} & $355.2 \pm 32.3^{\#+}$ & $200.5 \pm 51.1^{+}$ & $11.0 \pm 3.5^{\#+}$ & $85.6 \pm 0.7^{\#+}$ & $44.7 \pm 0.7^{\#+}$ & $52.0 \pm 4.8^{\#+}$ \\
\hline \multirow{3}{*}{35} & \multicolumn{2}{|c|}{ irradiated non-treated } & $1.8 \pm 0.20^{\#}$ & $0.6 \pm 0.10^{\#}$ & $0.4 \pm 0.10^{\#}$ & $0.3 \pm 0.01^{\#}$ & $0.1 \pm 0.01^{\#}$ & $0.2 \pm 0.01^{\#}$ \\
\hline & \multirow[b]{2}{*}{ autotransplantation } & fibroblasts & $45.8 \pm 4.1^{\#}$ & $28.2 \pm 7.1^{\#}$ & $27.7 \pm 8.8^{\#}$ & $23.4 \pm 0.2^{\#}$ & $10.2 \pm 0.2^{\#}$ & $12.5 \pm 1.2^{\#}$ \\
\hline & & $\begin{array}{l}\text { fibroblasts and } \\
\text { keratinocytes }\end{array}$ & $548.3 \pm 49.9^{\#+}$ & $260.8 \pm 66.5^{+}$ & $186.2 \pm 59.6^{\#+}$ & $136.9 \pm 1.2^{\#+}$ & $71.5 \pm 1.2^{\#+}$ & $83.2 \pm 7.8^{+}$ \\
\hline
\end{tabular}

Note: see table 2 .

Similarly, in the burn area in irradiated non-treated animals on the 35th day after irradiation, expression of genes of hyaluronan synthases 1, 2 and 3, synthesizing hyaluronic acid of small, medium, and high weight, respectively, decreases (Table 4).

Thus autotransplantation of only fibroblasts even on the 35 th day after irradiation of animals increases the expression of genes of matrix proteins compared to normal only in the range of $8-13 \%$, and expression of hyaluronan synthases genes, on average, is $16.5 \%$. At the same time, autotransplantation with the mixture of fibroblasts and keratinocytes already on the 20th day after irradiation of animals significantly increases the gene expression of matrix proteins. For both types of collagen, it is $80 \%$ and for the minor regulatory 
proteins lies in the range of $40-55 \%$ of the expression of the corresponding genes in the intact animals. On the 35th day after irradiation of animals the gene expression of collagen type I is greater than the norm $27 \%$, the genes of collagen type III and decorin correspond to norm, and expression of genes of elastin, fibronectin, and vinculin represent $76 \%$, $80 \%$ and $42 \%$ of the expression of these genes in nonirradiated animals.

Effect of autotransplantation of fibroblasts and the mixture of fibroblasts and keratinocytes on the expression of genes of hyaluronan synthases in the area of radiation skin burn of guinea pigs (rflu/mg of tissue $) \times 10^{4}$

\begin{tabular}{|c|c|c|c|c|c|}
\hline \multirow{4}{*}{$\begin{array}{l}\text { Days after } \\
\text { irradiation }\end{array}$} & \multirow{3}{*}{\multicolumn{2}{|c|}{$\begin{array}{l}\text { The irradiation and treatment } \\
\text { of animals conditions }\end{array}$}} & \multicolumn{3}{|c|}{ Enzyme and its gene } \\
\hline & & & hyaluronan synthase 1 & hyaluronan synthase 2 & hyaluronan synthase 3 \\
\hline & & & HAS1 & HAS2 & HAS3 \\
\hline & non-irradiated & & $58.9 \pm 3.2$ & $58.6 \pm 3.2$ & $51.4 \pm 2.7$ \\
\hline \multirow{3}{*}{20} & \multicolumn{2}{|l|}{ irradiated non-treated } & $0.3 \pm 0.01^{\#}$ & $0.3 \pm 0.02^{\#}$ & $0.3 \pm 0.01^{\#}$ \\
\hline & \multirow{2}{*}{ autotransplantation } & fibroblasts & $0.2 \pm 0.01^{\#}$ & $0.19 \pm 0.01^{\#}$ & $0.16 \pm 0.01^{\#}$ \\
\hline & & fibroblasts and keratinocytes & $42.5 \pm 2.2^{\#+}$ & $42.6 \pm 2.3^{\#+}$ & $40.4 \pm 2.1^{\#+}$ \\
\hline \multirow{3}{*}{35} & \multicolumn{2}{|l|}{ irradiated non-treated } & $0.10 \pm 0.006^{\#}$ & $0.10 \pm 0.006^{\#}$ & $0.09 \pm 0.005^{\#}$ \\
\hline & \multirow{2}{*}{ autotransplantation } & fibroblasts & $9.6 \pm 0.5^{\#}$ & $9.5 \pm 0.5^{\#}$ & $8.8 \pm 0.4^{\#}$ \\
\hline & & fibroblasts and keratinocytes & $68.0 \pm 3.6^{\#+}$ & $68.1 \pm 3.7^{\#+}$ & $64.8 \pm 3.5^{\#+}$ \\
\hline
\end{tabular}

Note: see table 2 .

The change in gene expression of hyaluronan synthase in the area of burn during autotransplantation with the mixture of fibroblasts and keratinocytes looks similar. Thus, on the 20th day after irradiation of animals expression of these genes makes on average $74 \%$ compared to the norm, and on the 35 th day exceeds it on average of $18 \%$. Naturally, disorders of metabolism of extracellular matrix biopolymers in the radiation burn area are not only about the change in the expression of genes that determine production of these biopolymers, but also the genes of proteases and hyaluronidases, determining their disintegration.

Matrix metalloproteinases are essential in wound healing. By destroying the extracellular matrix and intercellular communications, they contribute to cell migration in reparation process. By interacting with cytokines, adhesion molecules of immune cells and receptors for signaling molecules, and by cleaving these molecules, they are involved in the regulation of inflammatory processes. Metalloproteinases regulate keratinocyte proliferation and differentiation of other cell types involved in scars resorption (BirkedalHansen, 1993; Parks, 2004). Similar role in the matrix restructuring during wound healing is performed by hyaluronidases (Meyer, 1971).
Table 5 shows the results of the measurement of gene expression of matrix metalloproteinases and hyaluronidase in normal skin of control animals and in the area of skin burn of irradiated non-treated animals and those treated with both types of autotransplantation. As is evident, changes of gene expression of all these enzymes in the burn zone, both on the 20 th and on the 35 th day after irradiation using both types of autotransplantation are parallel to the corresponding changes of the expression of the structural and minor biopolymers. On the 35 th day after irradiation during the autotransplantation of the mixture of fibroblasts and keratinocytes, the expression of genes MMP1, MMP2, MMP3, MMP7, MMP9 and hyaluronidase in the burn exceeds the corresponding expression of these genes in non-irradiated animals 2.5, 1.8, $1.2,1.8$ and 2.8 times.

Under the same conditions the gene expression of collagen type I and hyaluronan synthases exceeds the norm as well (Tables 3 and 4), which may cause the development of scar tissue in the healing wound. All of this indicates the existence of positive feedback, which is coordinating changes in gene expression of the structural biopolymers and their proteases and hyaluronidases genes during the process of tissue therapy with the mixture of fibroblasts and keratinocytes.

Table 5

Effect of autotransplantation of fibroblasts and the mixture of fibroblasts and keratinocytes on the expression of genes of matrix metalloproteinases (MMP) and hyaluronidase (HYLA) in the area of radiation skin burn of guinea pigs (rflu/mg of tissue) $\times 10^{4}$

\begin{tabular}{|c|c|c|c|c|c|c|c|c|}
\hline \multirow{3}{*}{$\begin{array}{l}\text { Days after } \\
\text { irradiation }\end{array}$} & \multirow{2}{*}{\multicolumn{2}{|c|}{$\begin{array}{c}\text { The irradiation and treatment } \\
\text { of animals conditions }\end{array}$}} & \multicolumn{6}{|c|}{ Enzyme and its gene } \\
\hline & & & MMP1 & MMP2 & MMP3 & MMP7 & MMP9 & HYLA \\
\hline & non-irradic & & $32.6 \pm 1.8$ & $40.3 \pm 2.2$ & $58.4 \pm 3.1$ & $40.5 \pm 2.2$ & $29.6 \pm 1.6$ & $39.7 \pm 2.1$ \\
\hline \multirow{3}{*}{20} & \multicolumn{2}{|c|}{ irradiated non-treated } & $0.17 \pm 0.01^{\#}$ & $0.2 \pm 0.01^{\#}$ & $0.3 \pm 0.01^{\#}$ & $0.2 \pm 0.01^{\#}$ & $0.16 \pm 0.01^{\#}$ & $0.2 \pm 0.01^{\#}$ \\
\hline & \multirow{2}{*}{$\begin{array}{l}\text { autotrans- } \\
\text { plantation }\end{array}$} & fibroblasts & $0.07 \pm 0.003^{\#}$ & $0.1 \pm 0.006^{\#}$ & $0.2 \pm 0.01^{\#}$ & $0.1 \pm 0.006^{\#}$ & $0.05 \pm 0.003^{\#}$ & $0.1 \pm 0.005^{\#}$ \\
\hline & & $\begin{array}{l}\text { fibroblasts } \\
\text { and keratinocytes }\end{array}$ & $44.6 \pm 2.5^{\#+}$ & $6.2 \pm 2.5^{+}$ & $42.4 \pm 2.2^{\#+}$ & $46.2 \pm 2.5^{+}$ & $44.7 \pm 2.55^{\#+}$ & $46.7 \pm 2.5^{\#+}$ \\
\hline \multirow{3}{*}{35} & \multicolumn{2}{|c|}{ irradiated non-treated } & $0.06 \pm 0.003^{\#}$ & $0.07 \pm 0.003^{\#}$ & $0.1 \pm 0.006^{\#}$ & $0.07 \pm 0.004^{\#}$ & $0.04 \pm 0.002^{\#}$ & $0.07 \pm 0.004^{\#}$ \\
\hline & \multirow[b]{2}{*}{$\begin{array}{l}\text { autotrans- } \\
\text { plantation }\end{array}$} & fibroblasts & $6.9 \pm 0.3^{\#}$ & $7.7 \pm 0.4^{\#}$ & $9.4 \pm 0.5^{\#}$ & $7.7 \pm 0.4^{\#}$ & $6.6 \pm 0.3^{\#}$ & $7.6 \pm 0.4^{\#}$ \\
\hline & & $\begin{array}{l}\text { fibroblasts } \\
\text { and keratinocytes }\end{array}$ & $81.4 \pm 4.6^{\#+}$ & $73.8 \pm 4.1^{\#+}$ & $68.9 \pm 3.7^{\#+}$ & $73.8 \pm 4.06^{\#+}$ & $81.6 \pm 4.6^{\#+}$ & $84.8 \pm 4.6^{\#+}$ \\
\hline
\end{tabular}

Note: see table 2 .

Our findings indicate that both types of autotransplantation result in two interacting mechanisms - this is, firstly, the

inhibition of the radiation burn development and radiation ulcer formation, and, secondly, the intensification of the 
reparation processes. The efficiency of therapeutic properties of auto-fibroblasts and keratinocytes mixture is higher than the efficiency of fibroblasts only. Of course, one reason for this is that total number of cells is approximately 1.5 times larger in each injection of mixture. Another reason is the production by keratinocytes of factors, which are biologically active to other types of cells. Of no less importance is the reason of higher efficiency of the auto-fibroblasts and keratinocytes mixture explained by their synergetic interaction in the processes of morphogenesis and skin damage reparation. The basis for this synergy is the system of positive feedbacks between these cells. Thus, both fibroblasts and keratinocytes produce growth factors and cytokines, which mutually stimulate each other to proliferate and synthesize the biologically active compounds which are necessary for interaction with other cell types (Boxman, 1993; Blomme, 1999; Marchese, 2001; Werner, 2007, Lee et al., 2013). All of this is well illustrated by the data in Table 6 .

Gene expression of transforming growth factor $\alpha$, which is synthesized by keratinocytes, and when included in the process of proliferation, stimulates the regeneration of tissues and wound healing (Coffey, 1995; Boilly et al., 2000; VogelHöpker et al., 2000; Pehlivan, 2001; Dörr et al.,2002; Praul et al., 2002), and on the 20th and 35th day after irradiation in the area of the burn is very low. Administration of autofibroblasts does not alter anything. But the administration of mixture of auto-fibroblasts and auto-keratinocytes already on the 20th day after irradiation increases the expression of this gene as compared with the norm by $15 \%$, and on 35 th day by $210 \%$. The more demonstrative is the situation with fibroblast growth factors 1,2 and 8 . The first two stimulate the growth of blood vessels, proliferation of fibroblasts and the filling of the wound with granulation tissue during the healing process. The last one, except for participation in angiogenesis, stimulates the expression of matrix metalloproteinases and degradation of the extracellular matrix, as a consequence, cell migration in the wound increases (Finklestein and Plomaritoglou, 2001). In the burn area of irradiated nontreated animals the gene expression of fibroblast growth factors is extremely low both on the 20th and on the 35th day of observation. Administration of auto-fibroblasts only on the 35 th day just slightly increases their expression on average by $17.5 \%$. At the same time, the administration of the mixture of auto-fibroblasts and auto-keratinocytes enhances gene expression of fibroblast growth factors 1, 2, 8 on the 20th day after irradiation by $61 \%, 80 \%$ and $76 \%$, and on 35 th day - on average by $123 \%$.

The essential role of fibroblasts and keratinocytes interaction in raising the therapeutic efficiency of their mixture compared to the action of fibroblasts only is indicated with the investigated biochemical parameters of inflammation (Table 7).

Effect of autotransplantation of fibroblasts and the mixture of fibroblasts and keratinocytes on the expression of genes of transforming growth factor $\alpha$ and fibroblast growth factors in the area of radiation skin burn of guinea pigs, (rflu/mg of tissue) $\times 10^{4}$

\begin{tabular}{|c|c|c|c|c|c|c|}
\hline \multirow{3}{*}{$\begin{array}{l}\text { Days after } \\
\text { irradiation }\end{array}$} & \multirow{2}{*}{\multicolumn{2}{|c|}{$\begin{array}{l}\text { The irradiation and treatment } \\
\text { of animals conditions }\end{array}$}} & \multicolumn{4}{|c|}{ Growth factors and their genes } \\
\hline & & & TGF $\alpha$ & FGF1 & FGF2 & FGF8 \\
\hline & non-irradiat & & $40.7 \pm 3.8$ & $79.1 \pm 7.3$ & $69.0 \pm 6.4$ & $54.7 \pm 5.2$ \\
\hline \multirow{3}{*}{20} & \multicolumn{2}{|c|}{ irradiated non-treated } & $0.2 \pm 0.02^{\#}$ & $0.4 \pm 0.04^{\#}$ & $0.4 \pm 0.03^{\#}$ & $0.3 \pm 0.03^{\#}$ \\
\hline & \multirow{2}{*}{$\begin{array}{l}\text { auto-trans- } \\
\text { plantation }\end{array}$} & fibroblasts & $0.10 \pm 0.01^{\#}$ & $0.30 \pm 0.02^{\#}$ & $0.25 \pm 0.02^{\#}$ & $0.18 \pm 0.02^{\#}$ \\
\hline & & fibroblasts and keratinocytes & $47.0 \pm 4.4^{+}$ & $48.6 \pm 4.5^{\#+}$ & $55.0 \pm 5.1^{\#+}$ & $41.4 \pm 3.9^{\#+}$ \\
\hline \multirow{3}{*}{35} & \multicolumn{2}{|c|}{ irradiated non-treated } & $0.07 \pm 0.01^{\#}$ & $0.13 \pm 0.01^{\#}$ & $0.13 \pm 0.01^{\#}$ & $0.10 \pm 0.01^{\#}$ \\
\hline & \multirow{2}{*}{\begin{tabular}{|l|} 
auto-trans- \\
plantation \\
\end{tabular}} & fibroblasts & $7.7 \pm 0.7^{\#}$ & $11.5 \pm 1.07^{\#}$ & $13.5 \pm 1.2^{\#}$ & $9.1 \pm 0.8^{\#}$ \\
\hline & & fibroblasts and keratinocytes & $85.2 \pm 8.1^{\#+}$ & $88.8 \pm 8.2^{\#+}$ & $88.0 \pm 8.1^{\#+}$ & $66.2 \pm 6.2^{\#+}$ \\
\hline
\end{tabular}

Note: see table 2 .

Effect of autotransplantation of fibroblasts and the mixture of fibroblasts and keratinocytes on the expression of genes of pro- and anti-inflammatory cytokines in the area of radiation skin burn of guinea pigs on the 20th day after irradiation (rflu/mg of tissue) $\times 10^{4}$

\begin{tabular}{|c|c|c|c|c|}
\hline \multirow{3}{*}{\multicolumn{2}{|c|}{ The irradiation and treatment of animals conditions }} & \multicolumn{3}{|c|}{ Cytokines and their genes } \\
\hline & & \multirow{2}{*}{$\begin{array}{c}\text { pro-inflammatory } \\
\text { IL-1 } \beta\end{array}$} & \multicolumn{2}{|c|}{ anti-inflammatory } \\
\hline & & & IL10 & TGF $\beta 1$ \\
\hline \multicolumn{2}{|l|}{ non-irradiated } & $61.0 \pm 5.7$ & $62.4 \pm 6.9$ & $44.6 \pm 11.6$ \\
\hline \multicolumn{2}{|l|}{ Irradiated non-treated } & $81.8 \pm 7.6^{\#}$ & $40.3 \pm 4.4^{\#}$ & $0.24 \pm 0.06^{\#}$ \\
\hline \multirow{2}{*}{ Autotransplantation } & fibroblasts & $81.1 \pm 7.6^{\#}$ & $45.2 \pm 5.0^{\#}$ & $0.18 \pm 0.04^{\#}$ \\
\hline & fibroblasts and keratinocytes & $60.1 \pm 5.6^{+}$ & $66.3 \pm 7.3^{+}$ & $48.4 \pm 12.6^{+}$ \\
\hline
\end{tabular}

Note: see table 2 .

Thus, on the 20th day after the irradiation of animals, the gene expression of pro-inflammatory cytokine - interleukin $1 \beta-$ in the burn area increases by $34 \%$ compared to the norm, what indicates the presence of inflammatory process in this area.

The administration of auto-fibroblasts into the burn within 20 days after irradiation of animals had no effect on this rate, but the administration of the mixture of auto-fibroblasts and auto-keratinocytes completely normalized it. Thus interleukin $1 \beta$ - the classical inflammatory mediator - is synthesized by keratinocytes and fibroblasts (Gabay, 2010).

These two methods of autotransplantation similarly affect gene expression of pro-inflammatory cytokine - interleukin 10 and transforming growth factor- $\beta 1$. In both cases, on the 20th day after irradiation of animals the expression of these 
genes in the burn area is reduced compared to the norm, what indicates the presence of inflammation. Complete normalization of expression occurs only after 20-day administration of the mixture of auto-fibroblasts and autokeratinocytes into the burn.

\section{Conclusions}

The daily 4.5-week volumetric autotransplantation of both fibroblasts and mixture of fibroblasts and keratinocytes into the area of local X-ray 3rd-degree skin burn in guinea pigs which is launched in 1 hour after irradiation, significantly inhibits the destruction of connective tissue, increases the number of living cells, normalizes biopolymer composition of connective tissue matrix in the burn zone, inhibits the inflammatory process, largely prevents the formation, development and growth of the radiation burn and radiation ulcer, and eventually leads to disappearance of the ulcer and to almost complete healing of burn.

This is based on the impact of autotransplantation leading to increased levels of gene expression of structural biopolymers and regulatory proteins in the radiation injury zone.

Therapeutic efficiency of autotransplantation of the mixture of fibroblasts and keratinocytes is significantly higher compared to the autotransplantation of fibroblasts only.

The reasons for it are both the number of living cells regularly replacing dead cells in the burn zone which is greater than the total and mutual stimulation of auto-fibroblasts and auto-keratinocytes to proliferate and synthesize biologically active substances - cytokines and growth factors, which induce tissue regeneration and healing of burn wound.

\section{References}

Altuhova, L.V., Gricenko, M.A., Kot, E.V., Kot, J.G., Persky, E.J., 2013. Normalizacija soderzhanija soedinitel'notkannyh kletok i strukturnyh biopolimerov mezhkletochnogo matriksa v zone lokal'nogo luchevogo ozhoga kozhi obemnoj transplantaciej autofibroblastov [Normalization of connective tissue cells and extracellular matrix structural biopolymers in the area of skin local radiation burn by volumetric autofibroblasts transplantation]. Visnik Harkivs'kogo Nacional'nogo Universitetu Imeni V.N. Karazina, Serija Biologija 18(1057), 5-8 (in Russian).

Arrayit, 2015. Complete Protocol for Arrayit DNA chip. Retrieved from URL http://arrayit.com/Products/DNA_Microarrays/DNA_Microarrays_DCH/dna_microarrays_dch.html

Benderitter, M., Gourmelon, P., Bey, E., Chapel, A., Clairand, I., Prat, M., 2010. New emerging concepts in the medical management of local radiation injury. Health Phys. 98, 851-857.

Birkedal-Hansen, H., 1993. Matrix metalloproteinases: A review. Crit. Rev. Oral Biol. Med. 4(2), 197-250.

Blomme, E.A., 1999. Parathyroid hormone-related protein is a positive regulator of keratinocyte growth factor expression by normal dermal fibroblasts. Mol. Cell Endocrinol. 152(12), 189-197.

Boilly, B., Vercoutter-Edouart, A.S., Hondermarck, H., Nurcombe, V., Le Bourhis, X., 2000. FGF signals for cell proliferation and migration through different pathways. Cytokine Growth Factor Rev. 11(4), 295-302.

Boxman, I., 1993. Modulation of IL-6 production and IL-1 activity by keratinocyte-fibroblast interaction. J. Invest. Dermatol. 101(3), 316-324.
Bushmanov, A.Y., Eremin, I.I., Moroz, B.B., Galstjan, I.A., Nadezhina, N.M., Slobodina, T.S., Grinakovskaja, O.S., 2012. Opyt sovremennogo lechenija luchevyh ozhogov u lic, podvergavshihsja vozdejstviju ionizirujushhego izluchenija [Experience of modern treatment of radiation burns in persons exposed to ionizing radiation]. Occupational Medicine and Industrial Ecology 10, 20-27 (in Russian).

Coffey, R., 1995. Basic actions of transforming growth factor- $\alpha$ and related peptides. Eur. J. Gastroen. Hepat. 7, 923-931.

Dörr, W., Spek, K., Farre, C.L., 2002. The effect of keratinocyte growth factor on healing of manifest radiation ulcers in mouse tongue epithelium. Cell Prolif. 35(Suppl. 1), 86-92.

Eldashov, S.V., 2013. Jeksperimental'noe obosnovanie sovremennyh metodov hirurgicheskogo lechenija sochetannyh luchevyh porazhenij [Experimental study of modern methods of surgical treatment of combined radiation injuries]. St. Petersburg (in Russian).

ETS No. 170, 1998. Protocol of amendment to the European convention for the protection of vertebrate animals used for experimental and other scientific purposes, Strasbourg, Retrieved from URL www.echr-base.ru/CED170.jsp

Finklestein, S., Plomaritoglou, A., 2001. Growth factors. Head trauma: Basic, preclinical, and clinical directions. New York, Wiley, 165-187.

Gabay, C., 2010. IL-1 pathways in inflammation and human diseases. Nat. Rev. Rheumatol. 6, 232-241.

Gerasimova, L.I., Nazarenko, G.I., 2005. Termicheskie i radiatsionnie ozhogy [Thermic and radiation burn]. Medicine, Moscow (in Russian).

Glantz, S.A., 2007. Primer of Biostatistics, 4th Edition. McGraw-Hill, New York.

Groeber, F., Holeiter, M., Hampel, M., Hinderer, S., SchenkeLayland, K., 2012. Skin tissue engineering - in vivo and in vitro applications. Clin. Plast. Surg. 39, 33-58.

Hatzistergos, K.E., Blum, A., Ince, T.A., Grichnik, J.M., Hare, J.M., 2011. What is the oncologic risk of stem cell treatment for heart disease. Circ. Res. 108, 1300-1303.

Haubner, F.K., Ohmann, E., Pohl, F., Strutz, J., Gassner, H.G., 2012. Wound healing after radiation therapy. Review of the literature. Radiat. Oncol. 7, 162-170.

Herberts, C.A., Kwa, M.S.G., Hermsen, H.P.H., 2011. Risk factors in the development of stem cell therapy. J. Transl. Med. 9, 29-42.

Histomix, 2008. Protokol obrabotki soedinitel'noj tkani v parafinovyh srezah dlja okrashivanija alcianovym sinim [The protocol of processing of connective tissue in paraffin sections for Alcian blue staining]. Retrieved from URL www.histomix.ru/product 4.html.

Histomix, 2010. Protokol obrabotki soedinitel'noj tkani v parafinovyh srezah dlja okrashivanija po Van-Gizonu [The protocol of processing of connective tissue in paraffin sections for Van Gieson staining]. Retrieved from URL www.histomix.ru/product_5.html.

Histomix, 2012. Protocol of processing of connective tissue in paraffin sections with hematoxylin and eosin. Retrieved from URL www.histomix.ru/product_17.html.

Histopathology, 2013. Gistohimicheskaja identifikacija uglevodov [Histochemical identification of carbohydrates]. Retrieved from URL www.histopathology.narod.ru/ documents/gistohimija_uglevodov.html.

Huang, L., Burd, A., 2012. An update review of stem cell applications in burns and wound. Care. Indian J. Plast. Surg. 45(2), 229-236.

Imaris, 2011. Imaris for Cell Biologists. Retrieved from URL www.bitplane.com/imaris/imaris-for-cell-biologists.

Invitrogen, 2015. Tools for hybridization experiments in SecureSeal $^{\mathrm{TM}}$ Hybridization Chambers. Retrieved from URL www.tools.thermofisher.com/content/sfs/manuals/mp18200. pdf. 
Keller, G., 2000. Sohrannost' ineciruemyh autologichnyh chelovecheskih fibroblastov [Safety of injectable autologous human fibroblasts]. Bjul. Jeksp. Biol. Med. 130(8), 203-206.

Kligunenko, E.N., Leshhev, D.P., Slesarenko, S.V., Slinchenkov, V.V., Sorokina, E.J., 2005. Intensivnaja terapija ozhogovoj bolezni [Intensive therapy of burn disease]. MEDpress-inform, 144

Kot, J.G., Kot, E.V., Perskij, E.J., Polikarpova, A.V., Altuhova, L.V., 2013. Tormozhenie razvitija lokal'nogo luchevogo ozhoga objomnoj autotransplantaciej fibroblastov [Inhibition of local radiation burn development by volume fibroblast autotransplantation]. Dopovidi Nacional'noi Akademii Nauk Ukraini. Matematika, Prirodoznavstvo, Tehnichni Nauki 4, 144-147 (in Russian).

Laboratornaja Diagnostika, 2015. Immunologija, belki ostroj fazy vospalenija [Immunology, acute phase proteins of inflammation]. Retrieved from URL www.ld.ru/IFA/ilist14.html.

Lee, S.H., Jin, S.Y., Song, J.S., Seo, K.K., Cho, K.H., 2012. Paracrine effects of adipose-derived stem cells on keratinocytes and dermal fibroblasts. Ann. Dermatol. 24, 136-143.

Marchese, C., 2001. Fibroblast growth factor 10 induces proliferation and differentiation of human primary cultured keratinocytes. J. Invest. Dermatol. 116(4), 623-628.

Marionnet, C., Pierrard, C., 2006. Interactions between fibroblasts and keratinocytes in morphogenesis of dermal epidermal junction in a model of reconstructed skin. J. Invest. Dermatol. 126, 971-979.

Meyer, K., 1971. Hyaluronidases. In.: The Enzimes. Academic Press, NY. 5, 307-320.

Miyamoto, S., 1998. Fibronectin and integrins in cell adhesion, signaling, and morphogenesis. Ann. N.Y. Acad. Sci. 857, 119-129.

Paramonov, B.A., Porembskij, J.O., Jablonskij, V.G., 2000. Ozhogi: Rukovodstvo dlja vrachej [Burns: Guide for physicians]. Speclit, St. Petersburg (in Russian).

Parks, W.C., 2004. Matrix metalloproteinases as modulators of inflammation and innate immunity. Nat. Rev. Immunol. 4(8), 617-629.

Pehlivan, T., Mansour, A., Spaczynski, R.Z., Duleba, A.J., 2001. Effects of transforming growth factors-alpha and -beta on proliferation and apoptosis of rat theca-interstitial cells. J. Endocrinol. 170(3), 639-645.

Praul, C.A., Ford, B.C., Leach, R.M., 2002. Effect of fibroblast growth factors $1,2,4,5,6,7,8,9$, and 10 on avian chondrocyte proliferation. J. Cell Biochem. 84(2), 359-366.

Qiagen, 2013. Qiagen ${ }^{\circledR}$ RNeasy FFPE Handbook. Manual for purification of total RNA from formalin-fixed, paraffin- embedded tissue sections. Retrieved from URL www.qiagen.com/ru/resources.

Qiagen, 2015. QIAGEN® OneStepRT-PCR Handbook. Manual for fast and highly sensitive one-step RT-PCR. Retrieved from URL www.qiagen.com/ru/resources.

Reed, C.C., 2002. The role of decorin in collagen fibrillogenesis and skin homeostasis. Glycoconjugate J. 19(4-5), 249-255.

Rennekampff, H., Kiessig, V., Griffey, S., 1997. Acellular human dermis promotes cultured keratinocyte engraftment. J. Burn Care Rehabil. 6, 535-544.

Rittié, L., 2005. Isolation and culture of skin fibroblasts. Methods Mol. Med. 117, 83-98.

Rowan, M.P., Cancio, L.C., Elster, E.A., Burmeister, D.M., Rose, L.F., Natesan, S., Chan, R.K., Christy, R.J., Chung, K.K., 2015. Burn wound healing and treatment: Review and advancements. Critical Care 19, 243-249.

Ryan, J.L., 2012. Ionizing radiation: The good, the bad, and the ugly. J. Invest. Dermatol. 132, 985-993.

Shapovalov, S.G., 2005. Sovremennye ranevye pokrytija v kombustiologii [Modern wound cover in combustiology]. Farm Mindeks-praktik 8, 38-46 (in Russian).

Shaw, A.J., 1996. Epithelial cell culture - A practical approach. Oxford University Press, Oxford, 179-200.

Takagi, R., Yamato, M., Murakami, D., Kondo, M., Yang, J., Ohki, T., 2011. Preparation of keratinocyte culture medium for the clinical applications of regenerative medicine. J. Tissue Eng. Regen. Med. 5, 63-73.

Tenenhaus, M., Rennekampff, H.O., 2007. Burn surgery. Clin. Plast. Surg. 34(4), 697-715.

Teng, M., Huang, Y., Zhang, H., 2014. Application of stems cells in wound healing. Wound Repair Regen. 22(2), 151-160.

Varani, J., Perone, P., 2007. Human skin in organ culture and human skin cells (keratinocytes and fibroblasts) in monolayer culture for assessment of chemically induced skin damage. Toxicol. Pathol. 35, 355-372.

Vogel-Höpker, A., Momose, T., Rohrer, H., Yasuda, K., Ishihara, L., Rapaport, D.H., 2000. Multiple functions of fibroblast growth factor-8 (FGF-8) in chick eye development. Mech. Dev. 94(1-2), 25-36.

Werner, S., Krieg, T., Smola, H., 2007. Keratinocyte-fibroblast interactions in wound healing. J. Invest. Dermatol. 127(5), 998-1008.

Yim, H., Cho, Y.S., Seo, C.H., Lee, B.C., Ko, J.H., Kim, D., 2010. The use of AlloDerm on major burn patients: AlloDerm prevents post-burn joint contracture. Burns 36, 322-328.

Надійшла до редколегї 18.09.2015 